\title{
Photosynthetic behaviour of Arabidopsis thaliana (Pa-1 accession) under salt stress
}

\author{
Walid Zorrig", Houneida Attia ${ }^{*}$, Najoua Msilini, Chayma Ouhibi, Mokhtar Lachaâl and Zeineb \\ Ouerghi
}

Physiologie et Biochimie de la Tolérance au Sel des Plantes, Faculté des Sciences de Tunis, Campus Universitaire, 2092 Tunis El Manar, Tunisie.

Accepted 22 July, 2011

\begin{abstract}
The growth reduction observed in many plants caused by salinity is often associated with a decrease in their photosynthetic capacity. This effect could be associated with the partial stomatal closure and/or the non-stomatal limitation which involves the decrease in ribulose-1,5-bisphosphate carboxylase oxygenase (RUBISCO) activity. The objective of this study was to explore the mechanisms of inhibited photosynthesis in Arabidopsis thaliana (Pa-1 accession) under salt stress. Pa-1 seeds grown on a solid substrate for 25 days on standard medium were challenged with $50 \mathrm{mM} \mathrm{NaCl}$ for 15 days. Harvests were carried out every five days by separating the rosette leaves and roots. Salt stress reduced growth by limiting the number of the rosette leaves and not their biomass. Accumulation of $\mathrm{Na}^{+}$and $\mathrm{Cl}^{-}$increased during the treatment period, whereas $\mathrm{K}^{+}$and $\mathrm{Ca}^{2+}$ accumulation were reduced in salt treatment. RUBISCO and phosphoenolpyruvate carboxylase (PEPC) activities were increased with the age of the leaves to a maximum after $\mathbf{1 0}$ days of treatment then later decreased. We concluded that the sensitivity of $\mathrm{Pa}-1$ to salinity may be due to a reduction in number of leaves, in the photosynthetic assimilation with stomatal closure and damage of the RUBISCO and PEPC activities.
\end{abstract}

Key words: Arabidopsis thaliana, photosynthetic parameters, salinity, ribulose-1,5-bisphosphate carboxylase oxygenase (RUBISCO), phosphoenolpyruvate carboxylase (PEPC).

\section{INTRODUCTION}

Excessive soil salinity is an important constraint limiting the distribution of plants in natural habitats, and also an increasingly severe agricultural problem in arid and semiarid regions (Flowers, 2004). Under salt stress, plants have evolved complex mechanisms allowing for adaptation to osmotic and ionic stress caused by high salinity. These mechanisms include osmotic adjustment by accumulation of compatible solutes (Bohnert et al., 1999; Yeo, 1998) and lowering the toxic concentration of ions in the cytoplasm by restriction of $\mathrm{Na}^{+}$influx or its sequestration into the vacuole and/or its extrusion (Binzel et al., 1988; Hajibagheri et al., 1987). The ability of plants to tolerate salt is thus a multigenic trait and is generally acknowledged to be determined by multiple biochemical pathways, among which are those that facilitate water retention or acquisition, maintain ion homeostasis and protect various vital functions (Parida and Das, 2005).

Overall, plant growth under salinity is significantly reduced due to the inhibition of leaf expansion and a decrease in photosynthesis (Lips, 1998). The decrease in photosynthetic rate has been attributed mainly to stomatal closure (Kaiser, 1987) but could also be at least partially a consequence of feedback inhibition due to the increase of sucrose in source leaves (Poljakoff- 
Mayber and Lerner, 1994; Stitt, 1987). In Arabidopsis thaliana, salt treatment results in various changes in the photo-synthetic apparatus, namely a loss of chlorophylls, and a decrease in the quantum yield of both darkadapted and excited photosystems (M'rah et al., 2006). In herbaceous species such as spinach, the photosynthesis of salt-stressed plants is initially constrained by resistance to $\mathrm{CO}_{2}$ diffusion (Delfine et al., 1998; 1999). When leaf salt $(\mathrm{Na})$ concentration is moderate, a remarkable increase of mesophyll resistance, coupled with an increase of sto-matal resistance, lowers the chloroplast $\mathrm{CO}_{2}$ concentra-tion and limits photosynthesis. Photosynthesis limi-tation is partially reversible if salt accumulation inside the leaves is reduced by irrigation with salt-free water (Delfine et al., 1999). An irreversible impairment of the photo-synthetic apparatus, associated with a reduction of ribulose-1,5- bisposphate carboxylase/oxygenase (RUBISCO) activity and content, occurs when the stress is prolonged and salt continues to accumulate in the leaves (Delfine et al., 1999).

A. thaliana has been widely adopted as a model species for plant functional genomics (Somerville and Koornneef, 2002). It is a glycophytic species, which tolerates only mild salinity. It can accomplish its whole reproductive cycle in the presence of $50 \mathrm{mM} \mathrm{NaCl}$, but with a clearly reduced growth rate and signs of cellular stress (Attia et al., 2008a). Over 750 natural accessions of $A$. thaliana have been collected from around the world and are available from seed stock centres. Only few of them have been extensively studied. Among them is the Columbia $(\mathrm{Col})$, the genome of which has been entirely sequenced (Arabidopsis Genome Initiative, 2000).

In this work, we studied the response of $A$. thaliana (Pa-1 accession) to $\mathrm{NaCl}(50 \mathrm{mM})$ during vegetative growth (after 15 days of treatment). Rosette growth [dry matter (DM) production] and ion accumulation were measured, along with the number and surface area of leaves. Chlorophyll content, stomatal conductance, RUBISCO and phosphoenolpyruvate carboxylase (PEPC) activities and protein content were estimated in young and old leaves with the overall aim to explore the mechanisms of the inhibited photosynthesis in $\mathrm{Pa}-1$ accession under salt stress.

\section{MATERIALS AND METHODS}

\section{General culture conditions}

Pa-1 seeds were purchased at Arabidopsis Biological Resource Centre (ABRC) (http://arabidopsis.org/) under reference N1438. The seedlings were irrigated with distilled water during the first 10 days, and then with a nutrient solution (Gay and Hauck, 1994) diluted one quarter and composed of: $4.0 \mathrm{mM} \mathrm{MgSO}_{4}, 0.625 \mathrm{mM}$ $\mathrm{KH}_{2} \mathrm{PO}_{4}, 0.5 \mathrm{mM} \mathrm{Ca}\left(\mathrm{NO}_{3}\right)_{2}, 1.25 \mathrm{mM} \mathrm{NH}_{4} \mathrm{NO}_{3}, 0.04 \mu \mathrm{M} \mathrm{MnSO}_{4}, 0.5$ $\mu \mathrm{M} \mathrm{ZnSO}, 0.05 \mathrm{H}_{3} \mathrm{BO}_{3}, 0.02 \mathrm{MoO}_{3}$ and $3 \mu \mathrm{M}$ FeEDTA. A 10-h photoperiod with $150 \mu \mathrm{mol} . \mathrm{m}^{-2} . \mathrm{s}^{-1} \mathrm{PAR}$ at the plant level was used. Day/night temperature and relative humidity regimes were $22^{\circ} \mathrm{C} / 18^{\circ} \mathrm{C}$ and $60 \% / 80 \%$ respectively.

\section{Growth and ion accumulation}

At the age of 30 days (12 leaf stage), the nutritive solution was added with $50 \mathrm{mM} \mathrm{NaCl}$. A control assay without salt addition was followed in parallel. Control and $\mathrm{NaCl}$ treated plants were harvested daily from day 0 (just prior to the time that salt treatment was applied) to 5, 10 and 15 days after the treatment began. Seven replicates per treatment were used for measuring the physiological parameters and three for the photosynthetic parameters.

\section{Plant analysis}

At each harvest, roots were gently surface dried and the leaves and root fresh weights were immediately determined. Then roots and all leaves of the rosette were photographed, and root elongation and the individual leaf surface areas were measured using the Optimas ${ }^{\circledR}$ software. The samples were oven-dried for $48 \mathrm{~h}$ at $70^{\circ} \mathrm{C}$ and weighted. lons were extracted from $25 \mathrm{mg}$ samples of dried tissues with $0.5 \% \mathrm{HNO}_{3}$ for $48 \mathrm{~h} . \mathrm{K}^{+}, \mathrm{Na}^{+}$and $\mathrm{Ca}^{2+}$ were assayed by flame photometry (Jenway PFP7 butane-air flame) using butane-air flame for the two former ions and acetylene-air for the latter one and $\mathrm{Cl}^{-}$ by coulometry (Butcher Cotlove).

\section{Ribulose 1,5-biphosphate (RUBP) carboxylation and PEPC assays}

The activities of ribulose-1,5-biphosphate carboxylase/ oxygenase (RUBISCO; EC 4.1.1.39) and PEPC (EC 4.1.1.31) were spectrophotometrically assayed according to Ouerghi et al. (2000). Fresh leaf samples were ground in $100 \mathrm{mM}$ Tris-bicine $(\mathrm{pH}$ 8.0) containing $1 \mathrm{mM}$ ethylenediaminetetraacetic acid (EDTA), $5 \%$ glycerol $(\mathrm{v} / \mathrm{v}), 5$ $\mathrm{mM} \mathrm{MgCl}, 1 \% \beta$-mercaptoethanol (v/v), $1 \mathrm{mM}$ phenylmethylsulfonyl fluoride (PMSF) and $5 \%$ polyvinylpyrrolidone (PVP) (w/v of sample FM), and centrifuged at $12000 \mathrm{~g}$ for $10 \mathrm{~min}$ at $4^{\circ} \mathrm{C}$. RUBISCO activity was assayed in a reaction medium containing $100 \mathrm{mM}$ Tris-bicine ( $\mathrm{pH} 8.0$ ), $10 \mathrm{mM} \mathrm{MgCl}$, $0.2 \mathrm{mM}$ EDTA, $5 \mathrm{mM}$ dithiothreitol (DTT), $40 \mathrm{mM} \mathrm{NaHCO}$, $4 \mathrm{mM}$ ATP, $0.2 \mathrm{mM} \mathrm{NADH}$, $0.2 \mathrm{mM}$ ribulose 1,5-biphosphate (RuBP) and one enzyme unit of 3phosphoglycerate kinase (PGK) and glyceralde-hydes 3-phosphate dehydrogenase (3-PGADH). The crude extract $(5 \mathrm{ml})$ was added to the reaction medium, and the activity was monitored at $340 \mathrm{~nm}$ for $10 \mathrm{~min}$. Enzyme activity was expressed as $\mu \mathrm{mol} \mathrm{min}^{-1} \mathrm{~g}^{-1}$ (three replicates per treatment). PEPC was mea-sured in a crude root extract. PEPC reaction mixture contained $100 \mathrm{mM}$ Tris-bicine $(\mathrm{pH}$

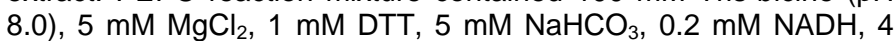
$\mathrm{mM}$ PEP, and 5 enzyme units of malate dehydro-genase (MDH). The crude extract was added to the reaction medium then the activity was monitored at $340 \mathrm{~nm}$ for $15 \mathrm{~min}$.

\section{Chlorophyll content}

The chlorophyll concentration was determined by spectro-photometry (Arnon, 1949) after repeated extraction of the pellet with $80 \%$ acetone at $4^{\circ} \mathrm{C}$.

\section{Extraction of leaf proteins}

At the harvest, rosette leaves fresh weights were immediately measured, then half of the samples were oven-dried for $48 \mathrm{~h}$ at $70^{\circ} \mathrm{C}$ for dry weight (DW) determination and half were excised and blended in liquid $\mathrm{N}_{2}$, and the powder was resuspended in a $50 \mathrm{mM}, \mathrm{pH} 7.5$ phosphate buffer containing $1 \mathrm{mM}$ EDTA, $1 \mathrm{mM}$ DTT, $5 \%$ glycerol and $5 \%$ polyvinylpyrrolidone, and centrifuged $(15000 \mathrm{~g})$ at $4^{\circ} \mathrm{C}$ for $20 \mathrm{~min}$. After extraction, leaf soluble protein content was deter- 

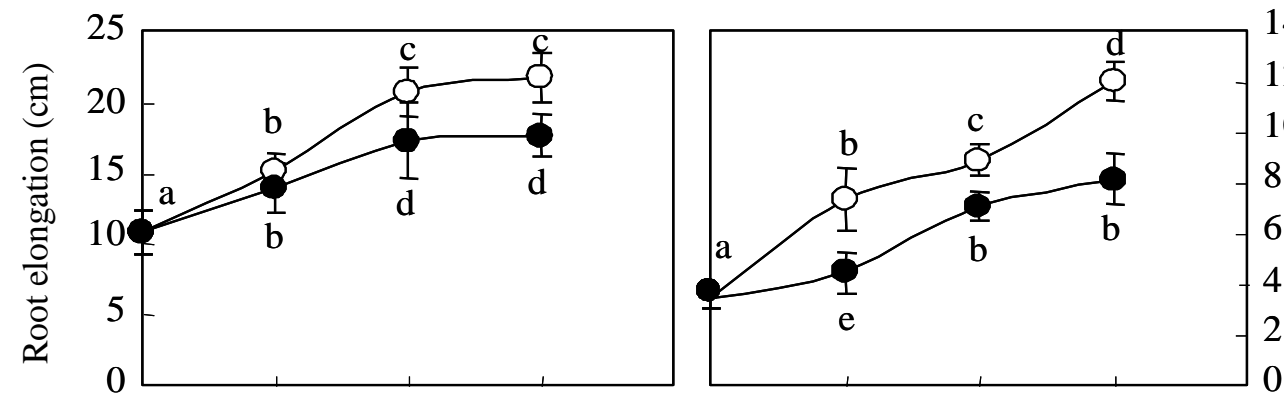

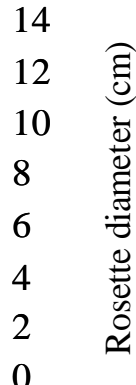
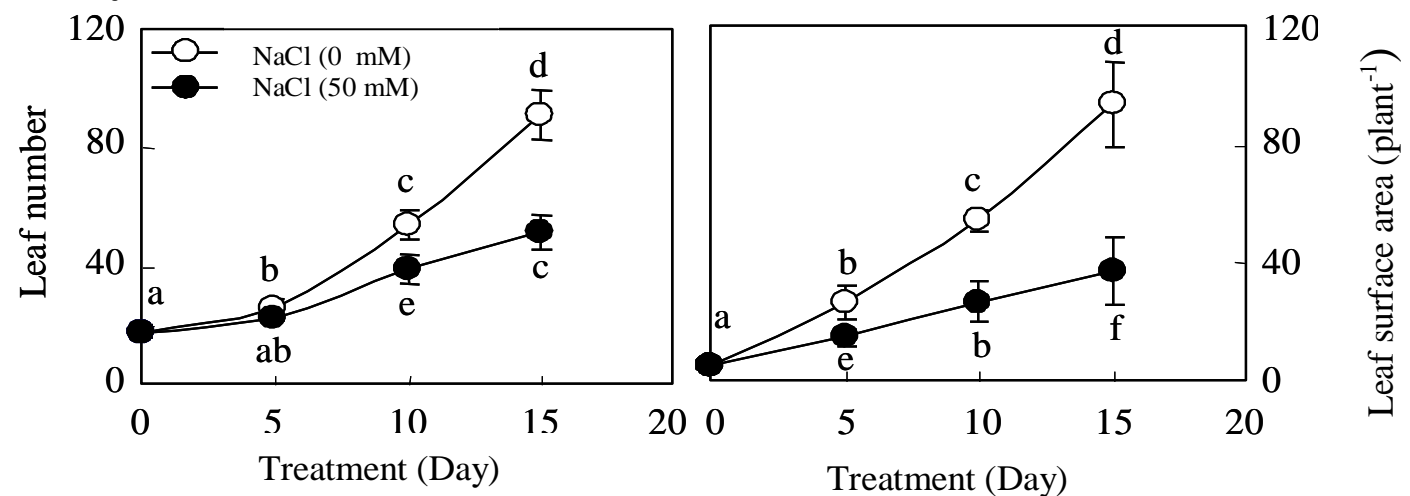

Figure 1. Effect of salt on root elongation and rosette characteristics of $A$. thaliana (Pa-1 accession). Thirty day-old plants were grown for the indicated period in the presence of $50 \mathrm{mM} \mathrm{NaCl}$. Means of 7 plants and confidence intervals for $p=0.05$. Means sharing the same letter are not significantly different at $p=0.01$ (ANOVA and mean comparison with Newman-Keuls test).

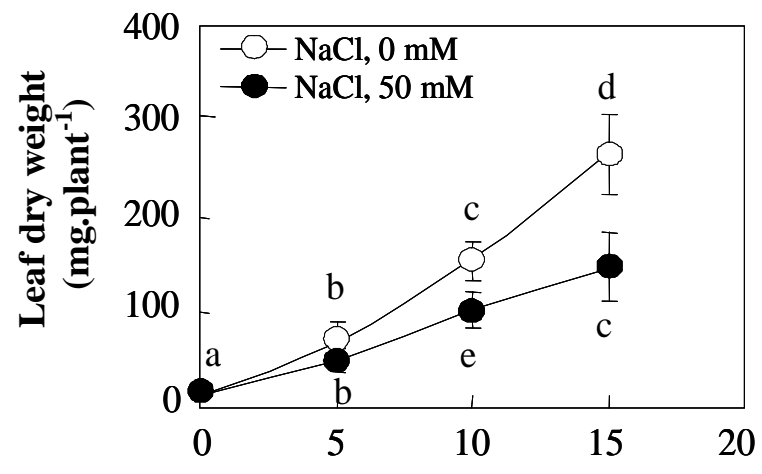

Treatment (day)

Figure 2. Effect of salt on rosette growth of $A$. thaliana $(\mathrm{Pa}-1$ accession): Thirty day-old plants were grown for the indicated period in the presence of $50 \mathrm{mM} \mathrm{NaCl}$. Means of 7 plants and confidence intervals for $p=0.05$. Means sharing the same letter are not significantly different at $p=0.01$ (ANOVA and mean comparison with Newman-Keuls test).

mined according to the method of Bradford (1976) using bovine serum albumin (BSA) as the standard. To minimize the variability, protein content were reported to the mass of dry matter.

\section{Statistics}

Statistical analysis was performed with Statistica ${ }^{\mathrm{TM}}$ software, using Two-way ANOVA and Newman-Keuls test for post-hoc mean comparison.

\section{RESULTS}

\section{Effect of $\mathrm{NaCl}$ on growth parameters}

$\mathrm{NaCl}$ caused a significant reduction for all of the considered growth parameters (Figures 1 and 2). The reduction was greater after long term salinity treatment (15 days) and it was more pronounced for leaf area parameter. The reduction in this parameter exceeded $50 \%$ after 15 days of treatment (Figure 1). For the root elongation, it appeared that it was the less affected parameter in comparison with the others (Figure 1). The rosette DW also was affected by $\mathrm{NaCl}$ treatment, especially after 10 and 15 days of $\mathrm{NaCl}$ treatment

\section{Inorganic ion concentrations}

The presence of $\mathrm{NaCl}$ in the rooting medium induced an important increase in $\mathrm{Na}^{+}$and $\mathrm{Cl}^{-}$concentrations in the leaves (Figure 3 ). During the first five days of salt treatment, a 40- and 20-fold increase in $\mathrm{Na}^{+}$and $\mathrm{Cl}^{-}$ concentration respectively, occurred in the leaf of the plants exposed to $50 \mathrm{mM} \mathrm{NaCl}$. At the time of harvest, the mean $\mathrm{K}^{+}$concentration in leaves was decreased by $2 \%$ per day while that of $\mathrm{Ca}^{2+}$ was stationary (Figure 3) 

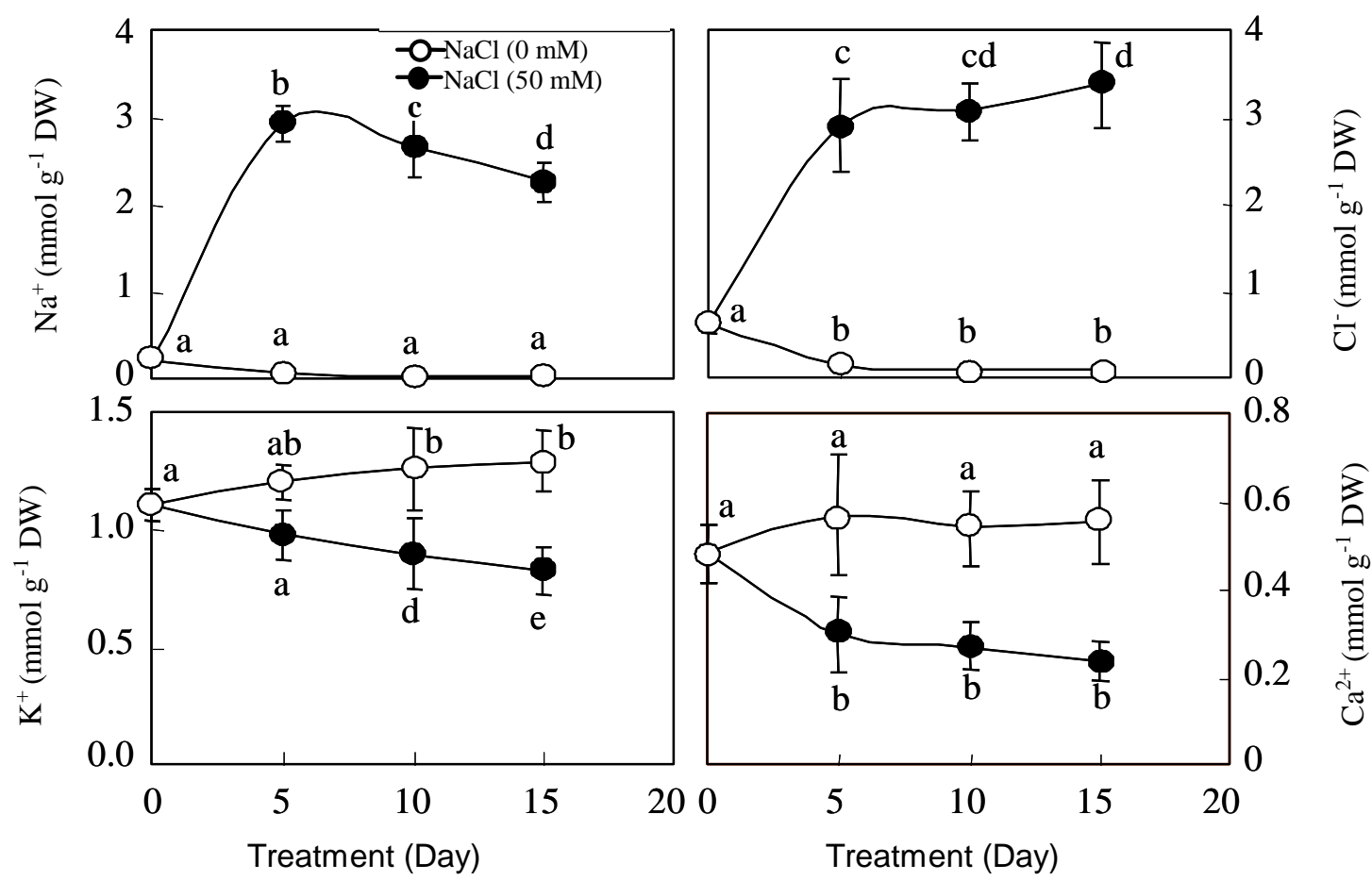

Figure 3. Effect of salt on ion accumulation in leaves of $A$. thaliana ( $\mathrm{Pa}-1$ accession): Thirty day-old plants were grown for the indicated period in the presence of $50 \mathrm{mM} \mathrm{NaCl}$. Means of 7 plants and confidence intervals for $p=0.05$. Means sharing the same letter are not significantly different at $p=0.01$ (ANOVA and mean comparison with Newman-Keuls test).

\section{Chlorophyll content}

In the control treatment, chlorophyll content was higher in young leaves than in older leaves (Figure 4). The Chlorophyll content responses to salt were opposite in the young and older leaves. In young leaves, salt treatment did not modify chlorophyll a but induced a decrease of chlorophyll $b$ and total especially at a long-term exposure to salt ( 15 days). In older leaves, the inhibition by salt concerned only chlorophyll a and chlorophyll b and the total was not affected. In both position leaves, chlorophyll $\mathrm{a} / \mathrm{b}$ ratio did not depend on treatment generally.

\section{Stomatal conductance}

On the control medium, stomatal conductance was the same in both young and older leaves (Figure 5) while in the presence of salt, this parameter decreased in the young leaves (20\%) but not in the older leaves (5\%).

\section{Enzyme activity}

The tolerance of RUBISCO capacity to $50 \mathrm{mM} \mathrm{NaCl}$ after 10 days of treatment was lower for younger leaves than for older leaves, as only $31-67 \%$ of the control activity was measured in younger and older leaves, respectively (Figure 6).
Also for PEPC capacity, the salt affected younger leaves more than the older leaves especially after 10 days of treatment. Only after five 5 days of treatment, did we observed a decrease in this activity of around 33\% for oldest leaves.

\section{Protein content}

The leaf protein content increased with the time of treatment both for the control and salt treatment in young leaves (Figure 7). For older leaves, protein content increased with $\mathrm{NaCl}$ in the medium only during the first five days of salt treatment. Two weeks after the beginning of the treatment, the protein content in rosette leaves of $\mathrm{Pa}-1$ was $63.2 \mathrm{mg} \mathrm{g}^{-1} \mathrm{DW}$ and $47.4 \mathrm{mg}^{-1} \mathrm{~g}^{-1} \mathrm{DW}$ for the control, and $96.8 \mathrm{mg} \mathrm{g}^{-1} \mathrm{DW}$ and $61.8 \mathrm{mg}^{-1} \mathrm{DW}$ for salt treatment $(50 \mathrm{mM} \mathrm{NaCl})$ in young and old leaves, respectively (Figure 7 ). This suggests a regulatory mechanism by biosynthesis of stress proteins.

\section{DISCUSSION}

The accumulation of $\mathrm{Na}^{+}$and $\mathrm{Cl}^{-}$in leaves of glycophytes is known to impose various stressors on the cells which alter their functional state, resulting in physiological stress (Gaspar et al., 2002). When severe, these have several 

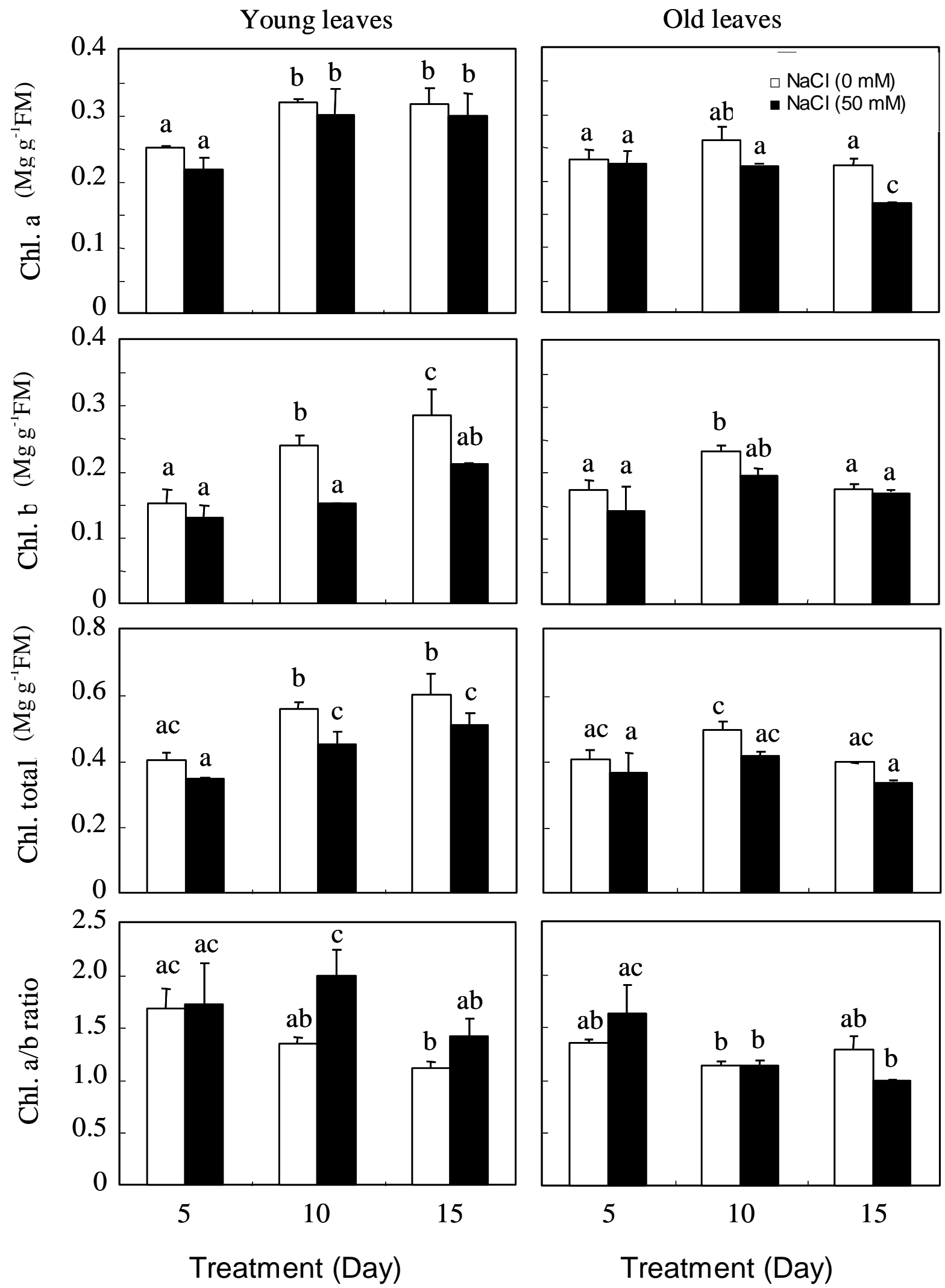

Figure 4. Effect of salt on chlorophyll content ( $\mathrm{mg} \mathrm{g}^{-1}$ leaf tissue) of young and old leaves of $A$. thaliana ( $P a-1$ accession). Thirty day-old plants were grown for the indicated period in the presence of $50 \mathrm{mM} \mathrm{NaCl}$. Means of 5 plants and confidence intervals for $p=0.05$. Means sharing the same letter are not significantly different at $p=0.01$ (ANOVA and mean comparison with Newman-Keuls test). 


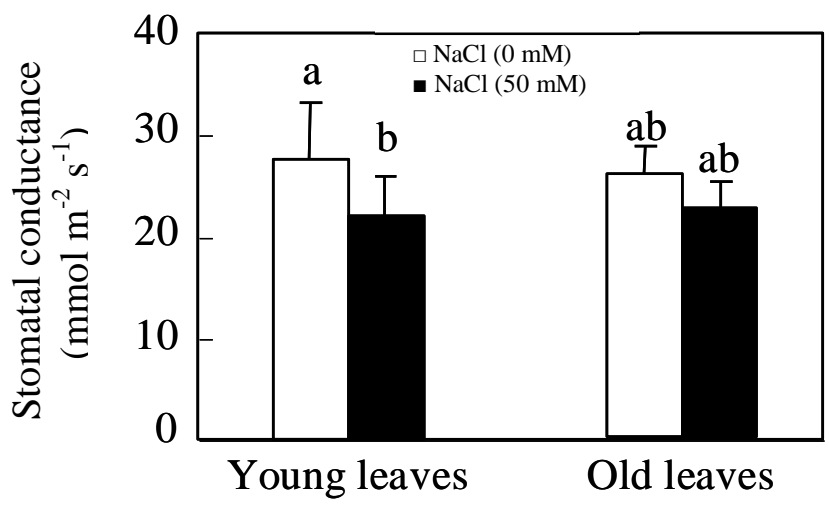

Figure 5. Effect of salt on stomatal conductance $\left(\mathrm{mmol} \mathrm{m} \mathrm{m}^{-2}\right)$ of young and old leaves of $A$. thaliana ( $P a-1$ accession). Thirty day-old plants were grown in the presence of $50 \mathrm{mM} \mathrm{NaCl}$. Means of 9 plants and confidence intervals for $p=0.05$. Means sharing the same letter are not significantly different at $p=0.01$ (ANOVA and mean comparison with Newman-Keuls test).

detrimental effects, corresponding to direct or indirect salt toxicity. The reduction in leaf development that accompanied salt treatment in this study presented three characteristics. First, it was observed during the first five days of salt treatment for Pa-1. Second, its importance regularly increased with times of treatment (Figures 1 and 2). Finally, it affected leaf area surface more than leaf number (Figure 1).

The $\mathrm{NaCl}$ concentration used here $(50 \mathrm{mM})$ induced distinct growth inhibition without classical symptoms of excessive $\mathrm{Na}^{+}$and $\mathrm{Cl}^{-}$accumulation in leaf tissues, such as extensive leaf dehydration, leaf necrosis, and plant death (Munns, 2002). The $\mathrm{Na}^{+}$and $\mathrm{Cl}^{-}$accumulation significantly increased, and they were associated with a pronounced inhibition of dry matter production (Figure 2). The observation that there were no toxic effects in $\mathrm{Pa}-1$ plants in salt conditions is in line with a general agreement that direct $\mathrm{Na}^{+}$and $\mathrm{Cl}^{-}$toxicity is not the main cause of salt-induced growth reduction (Hu et al., 2005). Under saline conditions, the $\mathrm{K}^{+}$concentration in many glycolphytes is severely reduced (Greenway and Munns, 1980). This was the case for $A$. thaliana, although $\mathrm{K}^{+}$concentration varied slightly among accessions for the same salinity treatment (Attia el al., 2008b). The highest decrease of $\mathrm{K}^{+}$took place in old leaves (data not shown). This suggests that Pa-1 accession is able to maintain relatively high $\mathrm{K}^{+}$levels in younger leaves, and this may act as the major monovalent cationic osmoticum in the presence of external salt. This mechanism may include the increase of $\mathrm{K}^{+}$translocation from old to young leaves (Marschner, 1995).

Growth is also affected by salt-induced damage in the mesophyll. Particularly, in the chloroplasts, an accumulation of starch might result from a reduced activity of the enzymes involved in its degradation (Salama et al., 1994) and/or an alteration of companion cells, involved in assi- milated collection in minor veins (Boughanmi et al., 2003).

The damage of thylakoids and grana is thought to be the consequence of salt-induced oxidative stress (Mitsuya et al., 2000). This alteration of membranes may expose chlorophyll molecules to peroxidation (Cakmak, 1994). In $\mathrm{Pa}-1$, this damage and the decrease in chlo-rophyll content ( $\mathrm{a}, \mathrm{b}$ and total) concerns both senescing and younger leaves. The decrease in chlorophyll content at higher salinity levels might be possibly due to changes in the lipid protein ratio of pigment-protein complexes or increased chlorophyllase activity (lyengar and Reddy, 1996). Our result are in agreement with several reports of decreased content of chlorophyll by salinity as reported in a number of glycophytes (Agaistian et al., 2000) and in certain halophytes such as Suaeda salsa (Congming et al., 2002) and Aegiceras corniculatum (Parida et al., 2004). A similar positive effect of $\mathrm{NaCl}$ salinity on the chlorophyll synthesis has been reported in Halopeplis ferfoliata and Excoecaria agallocha (Al-Zahrani and Hajar, 1998).

Since the duration of the salt treatment was rather long (15 days), these behaviours may be attributed to the balance of detrimental salt effects and biochemical protective mechanisms. Just after 10 days at $50 \mathrm{mM}$ $\mathrm{NaCl}$, the photosynthetic parameters were suppressed in A. thaliana (Pa-1 accession) leaves especially in young leaves, which could be explained by dramatic shrinkage of the RUBISCO and PEPC pools. In the same conditions of treatment, stomatal conductance was also affected after 15 days at $\mathrm{NaCl} 50 \mathrm{mM}$.

Phosphoenolpyruvate carboxylase activity in leaves was inhibited by salt at the first harvest for the oldest leaves (Figure 6). The induction of PEPC under saline treatment was reported in leaves of CAM plants (Yen et al., 1995). Guerrier (1988) also proposed that the levels of PEPC activity could be used as biochemical indicator of salt tolerance. It has been suggested that PEPC may be involved in the active regulation of the turgescence/ osmocontraction of cells of the inner cortex, which is one of the proposed mechanism of the $\mathrm{CO}_{2}$ diffusion barrier (Drevon et al., 1998). In this light, the boosted PEPC activity in the tolerant cultivar could improve regulation of $\mathrm{CO}_{2}$ diffusion. The role of PEPC in stomatal opening was also confirmed in epidermal strips of C3 plants using a PEPC inhibitor (Parvathi and Raghavendra, 1997; Asai et al., 2000). At the whole leaf level, the use of antisense and overexpression of PEPC in Solanum tuberosum also suggested that malate accumulation is involved in stomatal function (Gehlen et al., 1996). This showed that rates of stomatal opening increased in plants over expressing PEPC and decreased in plants with reduced levels of PEPC. However, low PEPC levels had no effect on steady-state stomatal conductance and overexpression of PEPC had only a marginal effect (Gehlen et al., 1996).

Photosynthesis parameters such as stomatal conduc- 


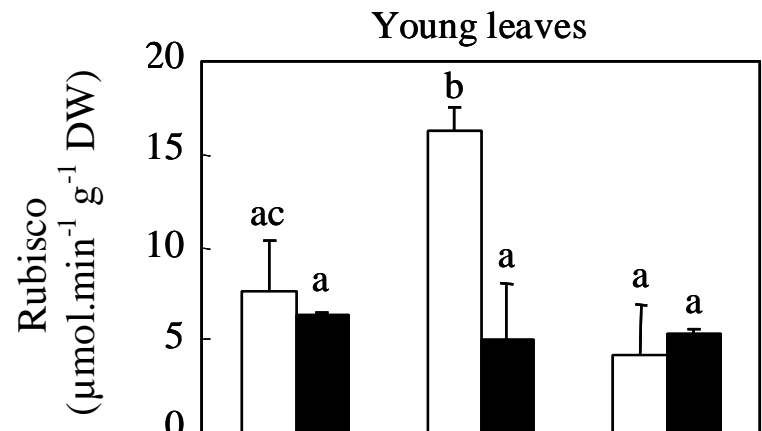

Old leaves

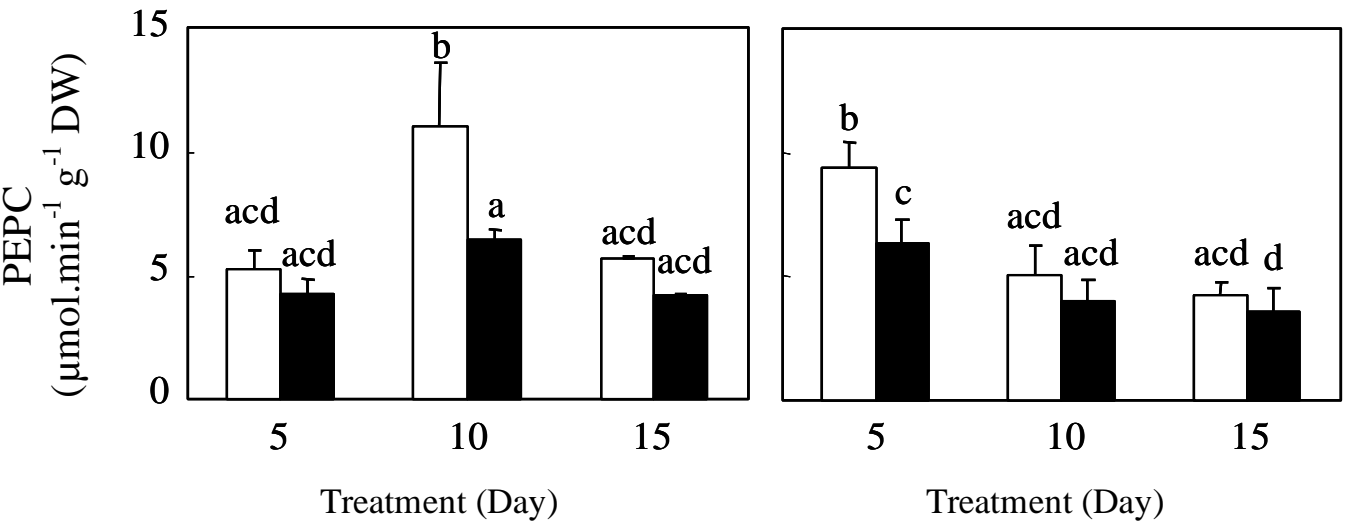

Figure 6. Effect of salt on RUBISCO and PEPC activities in young and old leaves of $A$. thaliana $(P a-1$ accession). Thirty day-old plants were grown for the indicated period in the presence of $50 \mathrm{mM} \mathrm{NaCl}$. Means of 4 plants and confidence intervals for $p=0.05$. Means sharing the same letter are not significantly different at $p=0.01$ (ANOVA and mean comparison with Newman-Keuls test).

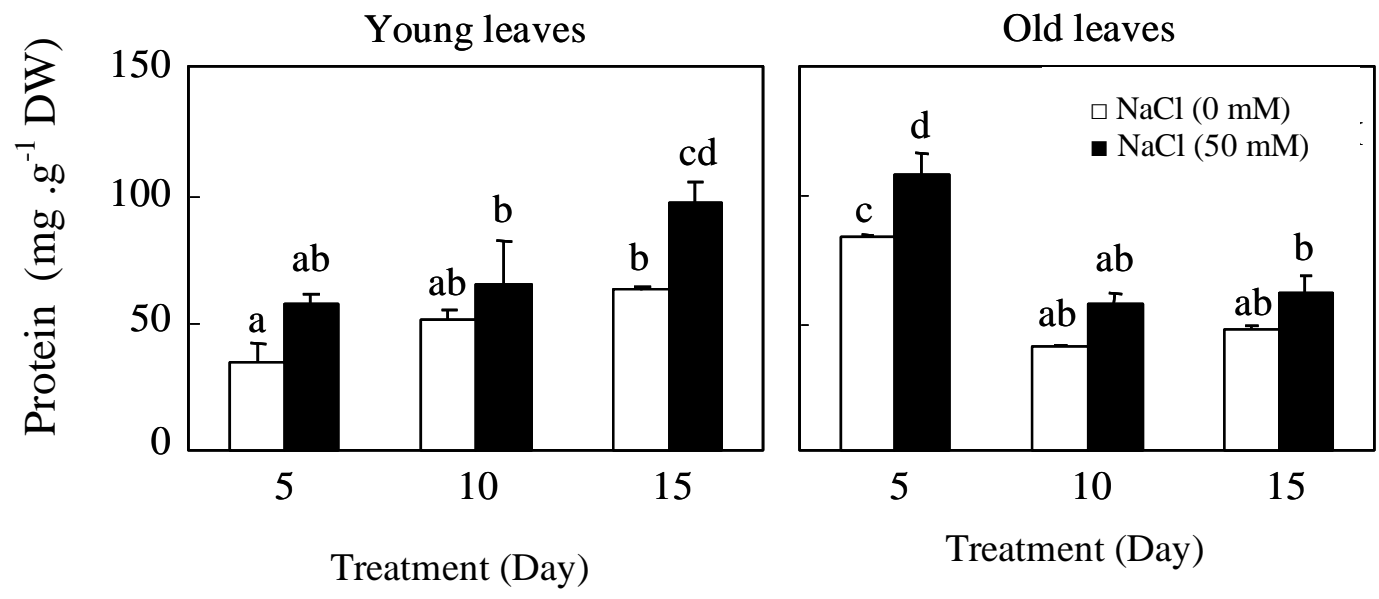

Figure 7. Effect of salt on protein content $\left(\mathrm{mg} \cdot \mathrm{g}^{-1} \mathrm{DW}\right)$ in young and old leaves of $A$. thaliana $(\mathrm{Pa}-1$ accession). Thirty day-old plants were grown for the indicated period in the presence of $50 \mathrm{mM} \mathrm{NaCl}$. Means of 4 plants and confidence intervals for $p=0.05$. Means sharing a same letter are not significantly different at $p=0.01$ (ANOVA and mean comparison with Newman-Keuls test).

tance and RUBISCO and PEPC activities were inhibited by salt stress, but to a variable extent in young and old leaves and with the time of treatment. In general, the highest inhibition of RUBISCO and PEPC was observed for younger leaves after 10 days of salt treatment (Figure 6). The $\mathrm{NaCl}$ application had a negative effect on the stomatal conductance. Although there can be strong corre- lations between increases in leaf ion concentrations and reductions in photosynthesis or stomatal conductance, there is yet no unequivocal evidence for causal relationships. Correlations can disappear when considering different leaves, or different salinities (Rawson et al., 1988). Experiments using different genotypes differing in rates of $\mathrm{Na}^{+}$or $\mathrm{Cl}^{-}$accumulation may be able to distin- 
guish between the effects of salt in the leaf, and salt in the soil. Alternatively, stress-relief experiments can show whether the salt in the leaf is causing the decrease in stomatal conductance or photosynthesis, as leaching the soil will quickly restore the water relations of the plant but not affecting salt levels in leaves. Reduced leaf expansion and stomatal conductance at high salinity as observed in our experiment are indicators that salinity has resulted in water deficit (Greenway and Munns, 1980).

It has been reported that salt accumulates prevalently in old leaves that are eventually dropped (Bongi and Loreto, 1989). This would allow young leaves to be relatively unaffected by salt and to efficiently photosynthesize, and this is similar to a mechanism of salt exclusion (Munns, 1993). In our experiment, a high salt accumulation was evident in old $\mathrm{Pa}-1$ leaves (data not shown), but stomatal conductance were inhibited only in young old leaves (Figure 6). Martínez-Ballesta et al. (2004) showed that stomatal conductance decline with time for the $\mathrm{NaCl}$ treatment in pepper plants, which may reflect reported decreases of stomatal conductance with plant age (Mencuccini and Grace, 1996). It has been proposed that the reduction of leaf gas exchange in response to salinity is due to an increase in leaf $\mathrm{Na}^{+}$ concentration (García-Legaz et al., 1993; Walker et al., 1993). However, other authors associated reductions in photosynthetic capacity and stomatal conductance with high concentrations of $\mathrm{Cl}^{-}$(Bañuls et al., 1997; GarcíaSanchez et al., 2002). In our plants, an effect of both $\mathrm{Na}^{+}$ and $\mathrm{Cl}^{-}$could have occurred, since there were reductions in $\mathrm{NaCl}$ treatment.

The decline of the stomatal conductance of younger leaves at $50 \mathrm{mM} \mathrm{NaCl}$ could be one of the causes of the responses of the plant water status, which was not measured, or a reaction to chemical messages from the roots to the decreased osmotic potential of the nutrient solution (Neuman and Smit, 1991). Stomatal conductance may also be lowered due to the antagonistic effect of $\mathrm{Na}$ on $\mathrm{K}$, as $\mathrm{K}$ is required for stomatal opening and closing (Ahmad and Jabeen, 2005).

Salt stress can restrict photosynthesis by decreasing green pigments (Sudhir and Murthy, 2004), suppressing RUBISCO activity (Soussi et al., 1998) and reducing stomatal conductance, thus affecting internal $\mathrm{CO}_{2}$ availability (Bethkey and Drew, 1992). Hence, the reduction of photosynthesis may, atleast in part, be a direct effect of $\mathrm{Na}^{+}$and $\mathrm{Cl}^{-}$ions, as observed in sorghum (Netondo et al., 2004) and orange (López-Climent et al., 2008) plants.

\section{Conclusion}

This study showed that after 15 days of salt treatment, plants of $A$. thaliana $\mathrm{Pa}-1$ accession, showed disruption of growth namely a decrease in the biomass of rosette leaves. The reduced growth was accompanied by disruption of mineral nutrition. However, among these effects, two seem to have more effect on plant growth. The first is related to the accumulation of extra-vascular $\mathrm{Na}^{+}$in rosette leaves, and the second is related to potassium nutrition, which may be a factor limiting growth. Under salt stress, $\mathrm{Pa}-1$ accession shows a decline in biomass, probably due to deactivation of RUBISCO and stomatal closure. Indeed, our results showed that salinity $(\mathrm{NaCl}$, $50 \mathrm{mM}$ ) significantly reduced the stomatal conductance response to the decreasing availability of water in the medium. The treated plants also showed a reduction of PEPC activity in their leaves.

\section{REFERENCES}

Agaistian P, Kingsley SJ, Vivekanandan M (2000). Effect of salinity on photosynthesis and biochemical characteristics in mulberry genotypes. Photosynthetica, 38: 287-290.

Ahmad R, Jabeen R (2005). Foliar spray of mineral elements antagonistic to sodium- a technique to induce salt tolerance in plants growing under saline conditions. Pak. J. Bot. 37: 913-920.

Al- Zahrani HS, Hajar AS (1998). Salt tolerance in the halophyte Halopeplis perfoliata (Forsk) Bge. Ex. Schweint. Effect of $\mathrm{NaCl}$ salinity on growth and ion uptake. Indian J. Plant Physiol. 3:32-35.

Arnon DI (1949). Copper enzymes in chloroplasts. Phenol oxidases in Beta vulgaris. Plant Physiol. 24: 1-15.

Asai N, Nakajima N, Tamaoki M, Kamada H, Kondo N (2000). Role of malate synthesis mediated by phosphoenolpyruvate carboxylase in guard cells in the regulation of stomatal movement. Plant Cell Physiol. 41: 10-15.

Attia H, Arnaud N, Karray N, Lachaal M (2008a). Long-term effects of mild salt stress on growth, ion accumulation and superoxide dismutase expression of Arabidopsis rosette leaves. Physiol. Plant. 132: 293-305.

Attia H, Karray N, Rabhi M, Lachaâl M (2008b). Salt-imposed restrictions on the uptake of macroelements by roots of Arabidopsis thaliana. Acta Physiol. Plant. 30: 723-727.

Bañuls J, Serna MD, Legaz F, Primo-Millo E (1997). Growth and gas exchange parameters of citrus plants stressed with different salts. J. Plant Physiol. 150:194-199.

Bethkey PC, Drew MC (1992). Stomatal and non-stomatal components to inhibition of photosynthesis in leaves of Capsicum annum during progressive exposure to $\mathrm{NaCl}$ salinity. Plant Physiol. 99: 219-226.

Binzel ML, Hess FD, Bressan RA, Hasegawa PM (1988). Intracellular compartmentation of ions in salt adapted tobacco cells. Plant Physiol. 86: 607-614.

Bohnert HJ, Su H, Shen B (1999). Molecular mechanisms of salinity tolerance. In: Shinozaki K, Yamaguchi-Shinozaki K (eds) Molecular Responses to Cold, Drought, Heat and Salt Stress in Higher Plants. University of Arizona, Arizona, pp. 29-60.

Bongi G, Loreto F (1989). Gas exchange properties of salt-stressed olive (Olea europaea L.) leaves. Plant Physiol. 90: 1408-1416.

Boughanmi N, Michonneau P, Verdus MC, Piton F, Ferjani E, Bizid E, Fleurat-Lessard $P$ (2003). Structural changes induced by $\mathrm{NaCl}$ in companion and transfer cells of Medicago sative blades. Protoplasma, 220: 179-187.

Bradford MM (1976). A rapid and sensitive method for the quantitation of microgram quantities of protein utilizing the principle of protein-dye binding. Anal. Biochem. 72: 248-254.

Cakmak I (1994). Activity of ascorbate-dependent $\mathrm{H}_{2} \mathrm{O}_{2}$-scavenging enzymes and leaf chlorosis are enhanced in magnesium- and potassium-deficient leaves, but not in phosphorus-deficient leaves. J. Exp. Bot. 45: 1259-1266.

Congming L, Nianwei Q, Qingtao L, Baoshan W, Tingyum K (2002). Does salt stress lead to increased susceptibility of photosystem II to photoinhibition and changes in photosynthetic pigment composition in halophyte Suaeda salsa grown outdoors. Plant Sci. 163: 1063-1068.

Delfine S, Alvino A, Villani MC, Loreto $F$ (1999). Restrictions to $\mathrm{CO}_{2}$ conductance and photosynthesis in spinach leaves recovering from salt 
stress. Plant Physiol. 119: 1101-1106.

Delfine S, Alvino A, Zacchini M, Loreto F (1998). Consequences of salt stress on conductance to $\mathrm{CO}_{2}$ diffusion, RUBISCO characteristics and anatomy of spinach leaves. Aust. J. Plant Physiol. 25: 395-402.

Flowers TJ (2004). Improving crop salt tolerance. J. Exp. Bot. 55(396): 307-319.

García-Legaz MF, Ortiz JM, Garcia-Lidon A, Cerda A (1993). Effect of salinity on growth, ion content and $\mathrm{CO}_{2}$ assimilation rate in lemon varieties on different rootstock. Physiol. Plant. 89: 427-432.

García-Sanchez F, Jofon J, Carvajal M, Syvertsen JP (2002). Gas exchange, chlorophyll and nutrient contents in relation to $\mathrm{Na}^{+}$and $\mathrm{Cl}^{-}$ accumulation in 'Sunburst' mandarin grafted on different rootstocks. Plant Sci. 162: 705-712.

Gaspar T, Franck T, Bisbis B, Kevers C, Jouve L, Hausman JF Dommes J (2002). Concepts in plant stress physiology. Application to plant tissue cultures. Plant Growth Regul. 37: 263-85.

Gay AP, Hauck B (1994). Acclimation of Lolium temulentum to enhanced carbon dioxide concentration. J. Exp. Bot. 45: 1133-1141.

Gehlen J, Panstruga R, Smets H, Merkelbach S, Kleines M, Porsch P, Fladung M, Becker I, Rademacher T, Hausler RE, Hirsch HJ (1996). Effects of altered phosphoenolpyruvate carboxylase activities on transgenic C3 plant Solanum tuberosum. Plant Mol. Biol. 32: 831848.

Greenway H, Munns R (1980). Mechanisms of salt tolerance in nonhalophytes. Annu. Rev. Plant Physiol. 31: 61-69.

Guerrier G (1988). Capacités PEPCase et MDH extraites des plantules germées en milieu salé: des paramètres biochimiques de l'écophysiologie de la plante? Seed Sci. Technol. 16: 571-578.

Hajibagheri MA, Harvey DMR, Flowers TJ (1987). Quantitative ion distribution within root cells of salt-sensitive and salt tolerant maize varieties. New Phytol. 105: 367-379.

Hu Y, Fricke W, Schmidhalter U (2005). Salinity and the growth of nonhalophytic grass leaves: the role of mineral nutrient distribution. Funct. Plant Biol. 32: 973-985.

lyengar ERR, Reddy MP (1996). Photosynthesis in high salt tolerant plants. In: Pesserkali M (ed). Hand Book of Photosynthesis. Marshal Deker. Baten Rose, USA, pp. 56-65.

Kaiser WM (1987). Effect of water deficit in photosynthetic capacity. Physiol. Planta, 71: 142-149.

Lips SH (1998). Nitrogen stress and plant growth regulation. In: Srivastava HS, Singh RP (eds) Nitrogen Nutrition and Plant Growth, IBH Publishing, Oxford and New Delhi, India, pp. 283-304.

López-Climent MF, Arbona V, Pérez-Clemente RM, Gómez-Cadenas A (2008). Relationship between salt tolerance and photosynthetic machinery performance in citrus. Environ. Exp. Bot. 62: 176-184.

M'rah S, Ouerghi Z, Berthomieu C, Havaux M, Jungas C, Hajji M, Grignon C, Lachaal M (2006). Effects of $\mathrm{NaCl}$ on the growth, ion accumulation and photosynthetic parameters of Thellungiella halophila. J. Plant Physiol. 163: 1022-1031.

Marschner H (1995). Mineral Nutrition of Higher Plants, Ed 2. Academic Press, London, p. 889.

Martínez-Ballesta MC, Martínez V, Carvajal M (2004). Osmotic adjustment, water relations and gas exchange in pepper plants grown under $\mathrm{NaCl}$ or KCl. Environ. Exp. Bot. 52: 161-174.

Mencuccini M, Grace J (1996). Developmental patterns of aboveground hydraulic conductance in a Scots pine (Pinus sylvestris $\mathrm{L}$ ) age sequence. Plant Cell Environ. 19: 939-948.
Mitsuya S, Takeoka Y, Miyake H (2000). Effect of salt stress on growth and cation compartmentation in leaves of two plant species differing in salt tolerance. J. Plant Physiol. 159: 137-146.

Munns R (1993). Physiological processes limiting plant growth in saline soils: some dogmas and hypotheses. Plant Cell Environ. 16: 15-24.

Munns R (2002). Comparative physiology of salt and water stress. Plant Cell Environ. 25: 239-250.

Netondo GW, Onyango JC, Beck E (2004). Sorghum and salinity. II. Gas exchange and chlorophyll fluorescence of sorghum under salt stress. Crop Sci. 44: 806-811.

Neuman DS, Smit BA (1991). The Influence of Leaf Water Status and ABA on Leaf Growth and Stomata of Phaseolus Seedlings with Hypoxic Roots. J. Exp. Bot. 42: 1499-1506.

Ouerghi Z, Cornic G, Roudani A, Ayadi A, Brulfert J (2000). Effect of $\mathrm{NaCl}$ on photosynthesis of two wheat species (Triticum durum and $T$. aestivum) differing in their sensitivity to salt stress. J. Plant Physiol. 156: 335-340.

Parida AK, Das AB (2005). Salt tolerance and salinity effects on plants: a review. Ecotoxicol. Environ. Saf. 60: 324-349.

Parida AK, Das AB, Mittra B (2004). Effect of salinity on biochemical components of the mangrove, Aegiceras corniculatum. Aquat. Bot. 80:77-87.

Parvathi K, Raghavendra AS (1997). Both RUBISCO and phosphoenolpyruvate carboxylase are beneficial for stomatal function in epidermal strips of Commelina benghalensis. Plant Sci. 124: 153157.

Poljakoff-Mayber A, Lerner HR (1994). Plants in saline environments. In: Pessarakli M (ed) Handbook of Plant and Crop Stress, Marcel Dekker, New York, pp. 65-96.

Rawson HM, Long MJ, Munns R (1988). Growth anddevelopment in $\mathrm{NaCl}$-treated plants. 1. Leaf $\mathrm{Na}^{+}$and $\mathrm{Cl}^{-}$concentrations do not determine gas exchange of leaf blades of barley. Aust. J. Plant Physiol. 15: 519-527.

Salama S, Trivedi S, Busheva M, Arafa AA, Garab G (1994). Effects of $\mathrm{NaCl}$ salinity on growth, cation accumulation, chloroplast structure and function in wheat cultivars differing in salt tolerance. J. Plant Physiol. 144: 241-247.

Somerville C, Koornneef M (2002). A fortunate choice: the history of Arabidopsis as a model plant. Nat. Rev. Genet. 3: 883-889.

Soussi M, Ocaña A, Lluch C (1998). Effects of salt stress on growth, photosynthesis and nitrogen fixation in chickpea (Cicer arietinum L.). J. Exp. Bot. 49: 1329-1337.

Stitt $\mathrm{M}$ (1987). Rising $\mathrm{CO}_{2}$ levels and their potential significance for carbon flow in photosynthetic cells. Plant Cell Environ. 14: 71047108.

Sudhir P, Murthy SDS (2004). Effects of salt stress on basic processes of photosynthesis. Photosynthetica, 42: 481-486.

Walker RR, Blackmore DH, Sung Q (1993). Carbon dioxide assimilation and foliar ion concentration in leaves of lemon (Citrus limon L.) trees irrigated with $\mathrm{NaCl}$ or $\mathrm{Na}_{2} \mathrm{SO}_{4}$. Aust. J. Plant Physiol. 20: 173-185.

Yen HE, Grimes HD, Edwards GE (1995). The effects of high salinity, water-deficit, and abscisic acid on phosphoenolpyruvate carboxylase activity and proline accumulation in Mesembryanthemum crystallinum cell cultures. J. Plant Physiol. 145: 557-564.

Yeo AR (1998). Molecular biology of salt tolerance in the context of whole-plant physiology. J. Exp. Bot. 49: 915-929. 